\title{
Tuberculosis in the era of anti-TNF-alpha therapy: Why does the risk still exist?
}

\author{
John Leonardo Torres-Castiblanco', Jorge Alberto Carrillo²,
} Daniel Hincapié-Urrego ${ }^{1}$, Adriana Rojas-Villarraga ${ }^{1}$

1 Centro de Estudio de Enfermedades Autoinmunes (CREA), Escuela de Medicina y Ciencias de la Salud, Universidad del Rosario, Bogotá, D.C., Colombia

2 Departamento de Radiología, Hospital Universitario Mayor-Méderi, Bogotá, D.C., Colombia

Rheumatoid arthritis is an autoimmune systemic disease characterized mainly by inflammatory compromise of diarthrodial joints. Multiple drug therapies have been developed to control the activity of rheumatoid arthritis, among them, the first line of disease-modifying antirheumatic drugs (DMARD), and novel drug therapies such as the anti-TNF alpha therapy, with satisfactory clinical outcomes. Despite this positive fact, the use of this therapy implies the risk of producing negative effects due to its mechanism of action, which has been associated with multiple infections, especially tuberculosis, making it necessary to use screen tests before resorting to this kind of drugs.

We present the case of a 58-year-old female patient, with a six-year history of rheumatoid arthritis. The patient developed disseminated tuberculosis with compatible radiological and histological findings after receiving treatment with infliximab (anti-TNF therapy). No test was performed to screen for latent tuberculosis infection prior to the administration of infliximab.

The performance of routine screenings tests for tuberculosis prior to anti-TNF alpha therapy plays an essential role in the detection of asymptomatic patients with latent tuberculosis. This is the only way to identify those patients who would benefit from anti-tuberculosis drugs before the initiation of anti-TNF alpha therapy, which makes the difference in the search of a significant reduction in the incidence of tuberculosis and its associated morbidity and mortality.

Key words: Mycobacterium tuberculosis; tuberculosis; diagnosis; arthritis, rheumatoid; risk factor; tumor necrosis factor-alpha; biological therapy; infliximab; Colombia.

doi: https://doi.org/10.7705/biomedica.v38i0.3458

La tuberculosis en la era del tratamiento con fármacos inhibidores del factor de necrosis tumoral alfa: ¿por qué persiste el riesgo?

La artritis reumatoidea es una enfermedad crónica de carácter autoinmunitario caracterizada principalmente por el compromiso inflamatorio de las articulaciones cartilaginosas. Se han desarrollado múltiples tratamientos farmacológicos para controlar el avance de la artritis reumatoidea, entre ellos, los fármacos antirreumáticos modificadores de la enfermedad, además de nuevos esquemas terapéuticos con inhibidores del factor de necrosis tumoral alfa, con resultados clínicos satisfactorios. Sin embargo, el uso de tales medicamentos no resulta inocuo, ya que se los ha asociado con diversos efectos secundarios, especialmente, infecciones como la tuberculosis, lo cual exige la aplicación de pruebas de tamización antes de utilizarlos.

Se reporta el caso de una paciente de 58 años de edad con artritis reumatoidea de seis años de evolución, que después de recibir tratamiento con uno de estos fármacos, el infliximab, desarrolló tuberculosis diseminada, cuyo diagnóstico se confirmó mediante radiología e histopatología. No se emplearon pruebas de detección de la tuberculosis latente antes de prescribirle el infliximab.

Las pruebas de tamización para tuberculosis deben emplearse de forma rutinaria, con el fin de detectar aquellos pacientes con tuberculosis latente, ya que es la única manera de determinar si se requiere profilaxis antituberculosa antes de administrar dichos fármacos, hecho que marca la diferencia cuando se busca disminuir la incidencia de tuberculosis y la consecuente morbimortalidad.

Palabras clave: Mycobacterium tuberculosis; tuberculosis; diagnóstico; artritis reumatoidea; factor de riesgo; factor de necrosis tumoral alfa; terapia biológica; infliximab; Colombia.

doi: https://doi.org/10.7705/biomedica.v38i0.3458

\footnotetext{
Author's contributions:

John Leonardo Torres-Castiblanco: Review of clinical history and scientific literature Jorge Alberto Carrillo: Interpretation of diagnostic images

Daniel Alejandro Hincapié and Adriana Rojas-Villarraga: Review of scientific literature

All authors participated in the drafting of the final manuscript.
} 
Rheumatoid arthritis is a chronic, complex, and heterogeneous autoimmune disease. It is characterized by the presence of long-standing inflammation of the diarthrodial joints resulting in a symmetric polyarthritis and synovial membrane hypertrophy, followed by progressive joint damage, bone and cartilage destruction, as well as deformity (1).

Joint damage and physical disability are the two major adverse outcomes of the disease reducing quality of life and causing premature mortality (2). Less joint damage and better physical function have been unequivocally shown to be a consequence of the early implementation of conventional synthetic disease-modifying anti-rheumatic drugs (csDMARD) in addition to glucocorticoids (3). However, some patients in therapy with csDMARD (even with the concomitant use of two drugs) still present clear signs of the disease, which has led to the research for novel drug therapies that would prevent the progression of the disease and have a positive impact on their quality of life.

In the last few decades, pathophysiological pathways related to autoimmune diseases have shown that the tumor necrosis factor (TNF) is one of the most relevant targets for treatment and remission induction, thus opening the way to the development of drugs such as adalimumab, etanercept, infliximab, certolizumab pegol, and golimumab, all of which act as TNF inhibitors (4).

In spite of the benefits associated with these new drugs, the risks related to blocking the TNF pathway must be acknowledged. A high predisposition to certain infections, particularly tuberculosis, is one of the most frequent complications of such blocking (5).

We present a case of disseminated tuberculosis in a rheumatoid arthritis patient under anti-TNF-alpha therapy and discuss the topic in the light of updated recommendations for tuberculosis prevention when administering this treatment.

\section{Case report}

A 58-year-old woman with a six-year history of rheumatoid arthritis was examined for a 10day history of headaches with $7 / 10$ intensity and

\footnotetext{
Corresponding author:

John Leonardo Torres-Castiblanco, Centro de Estudio de Enfermedades Autoinmunes (CREA), Escuela de Medicina y Ciencias de la Salud, Universidad del Rosario, Carrera $24 \mathrm{~N}^{\circ}$ 63C-69, Bogotá, D.C., Colombia

Telephone: (571) 3499650

jltcastiblanco@hotmail.com
}

Received: 25/07/16; accepted: 28/03/17 presence of unstable gait. Immunomodulatory therapy included methotrexate $10 \mathrm{mg} /$ week starting five years before and biological therapy for the last year (anti-TNF-alpha therapy: infliximab, $200 \mathrm{mg}$ every 6 weeks). Infliximab was started due to the failure of remission with csDMARD.

At the moment of hospitalization, the patient did not present any sign of rheumatoid arthritis activity (Clinical Diseases Activity Index: 0). A computed tomography (CT) scan of the brain was done showing a hypodense basal right lesion associated with vasogenic edema in the left frontal lobe upon which extension studies were requested. Brain magnetic resonance imaging showed supraand infratentorial lesions highly suggestive of caseous granulomas (figure 1). A chest CT showed centrilobular micronodules with soft tissue density and branched centrilobular linear densities (figure 2). Abdomino-pelvic CT showed iliac mesenteric and retroperitoneal lymphadenopathy and wall thickening of the distal ileum (figure 3), which is highly suggestive of tuberculosis as a first diagnostic possibility. Lymph node biopsy reported granulomatous lymphadenitis with acid-alcohol resistant bacilli, thus confirming the diagnosis.
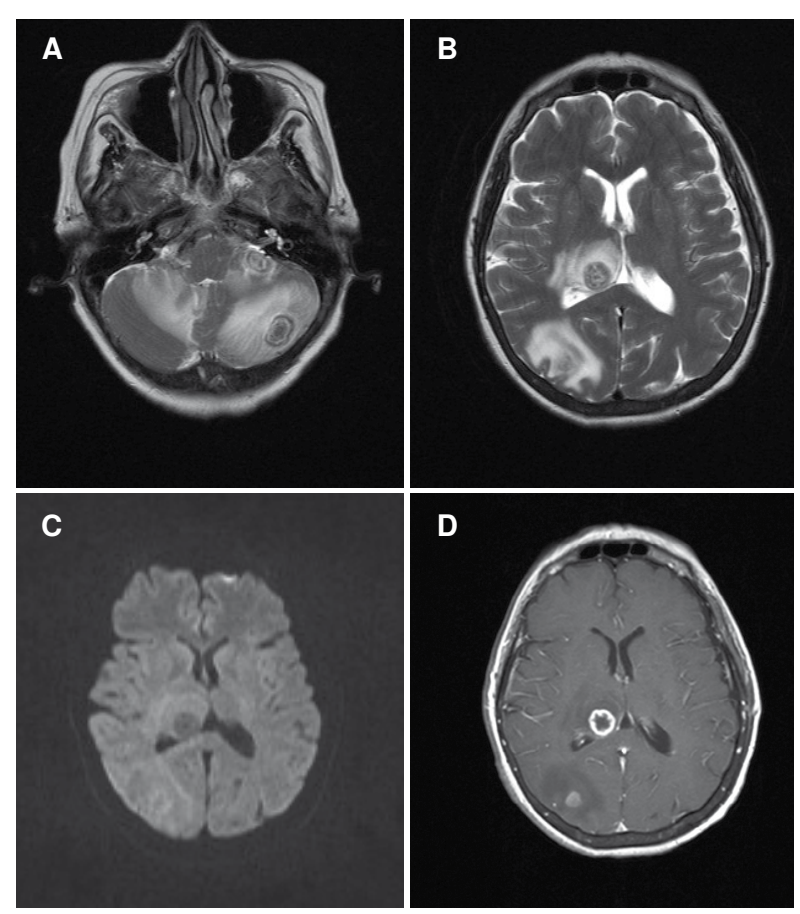

Figure 1. A, B. Axial T2-weighted brain MRI image showing multiple irregular intra-axial lesions with double central hypointense halo surrounded by vasogenic edema. C. Diffusionweighted image showing no restriction on the diffusion of water. $\mathbf{D}$. T1-weighted image showing an irregular thick ring enhancement 
Tuberculin skin tests (TST), interferon gamma release assays (IGRA) or chest $x$-rays were not done to screen for latent tuberculosis infection prior to the administration of infliximab.

The patient was started off with the classic fourdrug regime for the empiric treatment of tuberculosis (rifampicin, isoniazid, ethambutol, and pyrazinamide), and was discharged one week after admission. Anti-TNF-alpha therapy administration was suspended and maintenance management with prednisolone $7.5 \mathrm{mg} /$ day in addition to chloroquine $250 \mathrm{mg} /$ day was established.

\section{Discussion}

Given that an important fraction of rheumatoid arthritis patients was unable to achieve remission on treatment with csDMARD alone, and the better understanding of the pathophysiological pathways of the disease, new drugs have been developed to achieve clinical remission and improve patients' quality of life (6). However, these therapies are not $100 \%$ safe and innocuous, and can have severe side effects that put patients' lives at risk (7) as their action is not limited to blocking the abnormal pathways that lead to autoimmune disease development. There is no doubt about the benefits of using anti-TNF agents in rheumatoid arthritis patients. In fact, anti-TNF-alpha therapy for rheumatoid arthritis is now standard care, and it typically follows methotrexate (MTX) in patients who are not doing well. In the majority of cases $(70-80 \%)$, it is used jointly with MTX since the additional benefit of the combination has been demonstrated (4), i.e., organic chemicals of $\sim 400 \mathrm{Da}$ absorbable via the gut, this is no longer the case. There are now a plethora of important medicines which are proteins and injectable, which have dramatically improved the therapy of many inflammatory diseases and of cancer. Most of these are monoclonal antibodies, some are receptor Ig Fc fusion proteins, others are cytokines or enzymes. The key to this new aspect of therapeutics has been the filling of unmet needs, and the consequent commercial success, which promoted further research and development. The first 'biologic' for a common disease, rheumatoid arthritis (RA). Anti-TNF-alpha therapy also critically alters the regulation of inflammatory processes and the pathways of cell apoptosis, activation, recruitment and differentiation (8).

Five anti-TNF-alpha drugs are currently in clinical use. They have structural differences and, thus, their therapeutic indications differ $(6,7)$ (table 1 ).

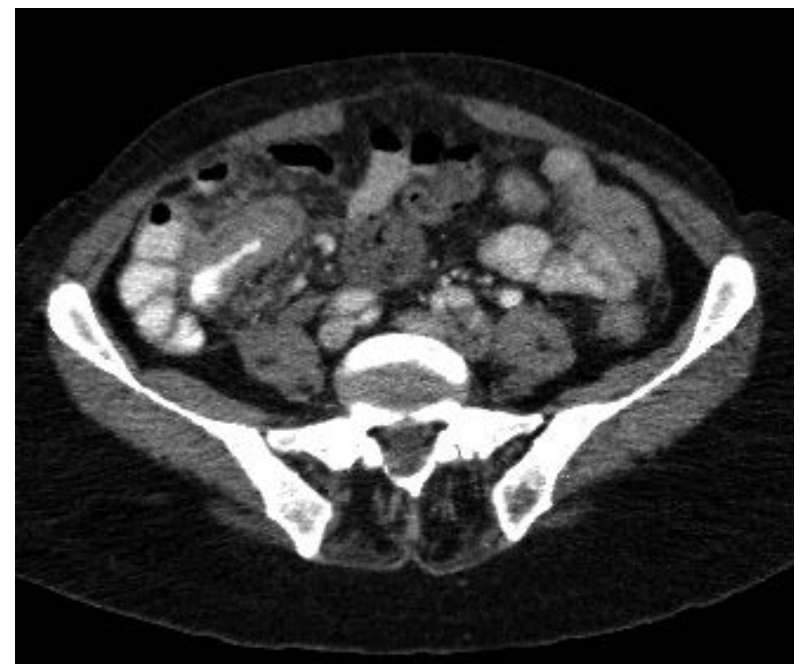

Figure 2. Abdominal $C T$ showing wall thickening of the distal ileum
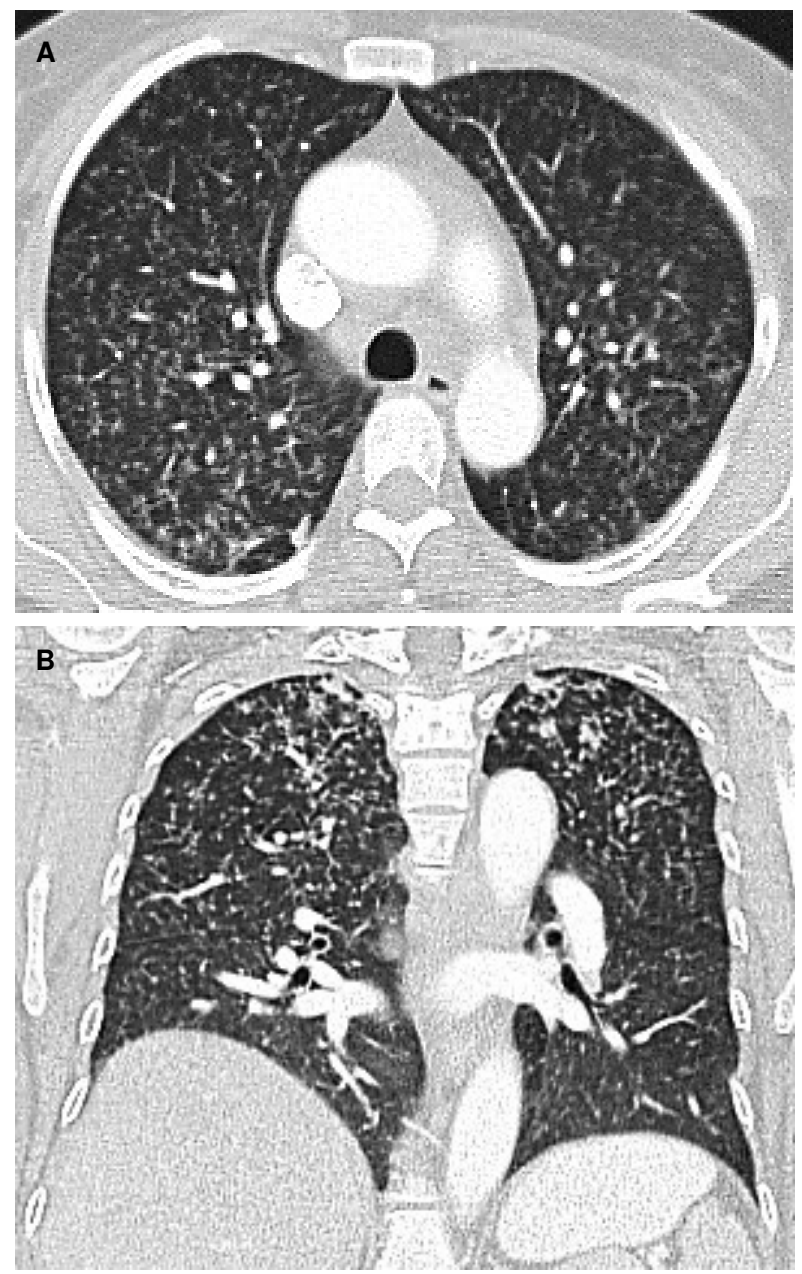

Figure 3. Chest CT showing centrilobular micronodules with apical dominance branched linear densities associated with "tree-in-bud" pattern 
The initiation of anti-TNF-alpha therapy is related to the development of multiple adverse effects including cardiovascular disease, malignancies and serious infections that may endanger the patient's life $(8,17,18)$. Among them, opportunistic infections are a major cause of morbidity and mortality, with a greater incidence of tuberculosis due to the pathophysiological role of TNF. In humans, TNF increases the phagocytic capacity of macrophages that ultimately go into apoptosis leading to the death of mycobacteria and stimulating the production of chemokines in the process. TNF also regulates the expression of adhesion molecules on endothelial cells which are important for recruiting mononuclear cells, an event that plays an important role in the formation of granulomas $(19,20)$. The absence of TNF prevents the formation of granulomas and, thus, infection cannot be contained (20).

According to the evidence available, the risk of developing tuberculosis increases 1.6-25 times after the start of anti-TNF-alpha therapy depending on the drug used $(7,21)$, a fact that is enhanced when tuberculosis incidence is very high (22).

In 1993, the World Health Organization (WHO) declared tuberculosis a health emergency potentially affecting one third of the world's population. This translates into additional costs in healthcare services and a negative impact on the economy. After AIDS, tuberculosis is currently the secondleading cause of death worldwide among diseases caused by infectious agents (23). According to the latest WHO statistics from 2013, the annual incidence of tuberculosis in Colombia is 32 per 100,000 in the general population (24). About onethird of the world's population is estimated to have latent tuberculosis infection $(23,25)$.
The incidence of tuberculosis in patients receiving anti-TNF alpha drugs varies depending on the type of therapy, as the specific characteristics of each biological agent differ (26). In the case of soluble TNF-alpha interaction with TNF-alpha receptor 1, this receptor is essential for both granuloma formation and containment of intracellular pathogens unlike membrane-bound TNF-alpha, which exerts its action via TNF receptor 2 , and whose role is less significant in infection containment and formation of granulomas $(20,27)$. These processes explain the following three key points:

- The increased risk of tuberculosis in patients receiving monoclonal antibodies (infliximab and adalimumab) vs. those patients receiving etanercept (28).

- The earlier appearance of tuberculosis in patients receiving therapy with infliximab $(8,19,20)$

- The use and benefits of infliximab in granulomatous diseases such as Crohn's disease and sarcoidosis $(12,29)$

Various international studies have shown the incidence rate of tuberculosis in patients receiving antiTNF-alpha therapy (table 2), but currently there are no local Colombian statistics available on the risk of active tuberculosis in patients with rheumatic diseases receiving anti-TNF-alpha therapy. However, several pulmonary and extrapulmonary tuberculosis cases in patients under anti-TNF-alpha therapy have been reported (34-41).

There have been multiple case reports worldwide of patients on biological therapy who have developed pulmonary and/or extrapulmonary tuberculosis $(42,43)$. In a multicenter retrospective study in the

Table 1. Anti-TNF-alpha therapy

\begin{tabular}{|c|c|c|}
\hline Anti-TNF-alpha & Mechanism of action & Clinical indications \\
\hline Infliximab $(9,10)$ & $\begin{array}{l}\text { A chimeric murine/human IgG1 } \\
\text { monoclonal antibody }\end{array}$ & $\begin{array}{l}\text { Rheumatoid arthritis, psoriasis, psoriatic arthritis, } \\
\text { ankylosing spondylitis, ulcerative colitis, Crohn's } \\
\text { disease and sarcoidosis }\end{array}$ \\
\hline Adalimumab (11) & $\begin{array}{l}\text { Fully human recombinant lgG1 } \\
\text { constant and variable regions }\end{array}$ & $\begin{array}{l}\text { Rheumatoid arthritis, psoriasis, psoriatic arthritis, } \\
\text { ankylosing spondylitis, juvenile rheumatoid } \\
\text { arthritis, ulcerative colitis and Crohn's disease }\end{array}$ \\
\hline Golimumab $(12,13)$ & $\begin{array}{l}\text { Fully human IgG1 constant and } \\
\text { variable regions }\end{array}$ & $\begin{array}{l}\text { Rheumatoid arthritis, psoriatic arthritis, ankylosing } \\
\text { spondylitis and ulcerative colitis }\end{array}$ \\
\hline $\begin{array}{l}\text { Certolizumab pegol } \\
(14-16)\end{array}$ & $\begin{array}{l}\text { Humanized antigen-binding fragment (FAB) } \\
\text { of a monoclonal antibody attached to a } \\
\text { polyethylene glycol }\end{array}$ & $\begin{array}{l}\text { Rheumatoid arthritis, psoriatic arthritis, ankylosing } \\
\text { spondylitis and Crohn's disease }\end{array}$ \\
\hline Etanercept (13) & $\begin{array}{l}\text { Soluble TNF receptor fusion protein composed } \\
\text { of two extracellular domains of human TNF-R2 } \\
\text { merged to the Fc fragment of human IgG1 }\end{array}$ & $\begin{array}{l}\text { Rheumatoid arthritis, psoriatic arthritis, psoriasis, } \\
\text { juvenile rheumatoid arthritis and ankylosing } \\
\text { spondylitis }\end{array}$ \\
\hline
\end{tabular}


Table 2. Tuberculosis in patients treated with anti-TNF-alpha therapy

\begin{tabular}{lcccc}
\hline Country & $\begin{array}{c}\text { Tuberculosis in the } \\
\text { general population }\end{array}$ & Adalimumab & Etanercept & Infliximab \\
\hline USA (30) & $6.2 / 100.000$ & & IR: $35 / 100.000$ & IR: $144 / 100.000$ \\
Spain (31) & $21 / 100.000$ & IR: $176 / 100.000$ & IR: $114 / 100.000$ & IR: $383 / 100.000$ \\
France (32) & $10 / 100.000$ & IR: $215 / 100.000$ & IR: $9.3 / 100.000$ & IR: $187.5 / 100.000$ \\
Portugal (33) & $33.74 / 100.000$ & 4 cases $/ 171$ patients & 1 case $/ 333$ patients & 8 cases/456 patients \\
\hline
\end{tabular}

IR: incidence rate

Netherlands on the importance of tuberculosis screening prior to the administration of biological therapy conducted in 611 patients with Crohn's disease, $75.8 \%$ of them were screened for tubercuIosis (TST, IGRA or chest radiography), and 3\% were positive. Half of this group received treatment for latent tuberculosis infection (isoniazid), and one untreated patient with a positive test developed pulmonary tuberculosis (44).

A retrospective study in the United States found that 130 patients had developed tuberculosis after the start of therapy with infliximab. However, only 67 of those who had started infliximab therapy in 2001, when the FDA issued the recommendation of tuberculosis screening prior to anti-TNF-alpha therapy, were evaluated. The study showed that 20 of the patients had not been screened for tuberculosis with a TST test while 23 patients had a chest $x$-ray, of whom 22 had normal results and one was reported as having unknown results. Among this group of patients, 14 developed pulmonary tuberculosis, five extrapulmonary tuberculosis and three disseminated tuberculosis (45).

The conclusion from these two studies is that some patients were not routinely screened for tuberculosis, and others did not receive prophylactic treatment in spite of the fact that they had a positive screening result compatible with latent tuberculosis infection. Another remarkable conclusion is that although initial tests were negative, the development of active tuberculosis infection during the treatment should not have been ruled out.

Clinical presentation of tuberculosis in a patient under anti-TNF-alpha therapy may vary from pulmonary to extrapulmonary or disseminated tuberculosis with an increased incidence of the latter two due to immunosuppression, as occurred with the case presented in this article $(46,47)$.

Likewise, it is clear that the diagnosis of an autoimmune disease, the use of cSDMARD and steroid therapy represent by themselves an increased risk of concomitant tuberculosis $(5,48-50)$ psoriatic arthritis (PsA, with a relative risk of 3.68 for rheumatoid arthritis, 3.4 for metothrexate, 11.7 for leflunomide and 2,4 for corticosteroids (47).

Taking into account these statistics and the role of TNF in tuberculosis control, as well as the increased risk of tuberculosis in patients with autoimmune diseases, as well as the use of DMARD therapy, tuberculosis screening before starting anti-TNF-alpha therapy is essential and mandatory $(5,8,29)$. Unfortunately, this was not observed in the case we present.

The Centers for Disease Control and Prevention (CDC) recommend screening patients for Mycobacterium tuberculosis risk factors before initiating anti-TNF-alpha therapy (30) in the following cases:

- People living in a congregate setting (e.g., jail, homeless shelter or chronic care facility)

- TST positive $>5 \mathrm{~mm}$

- Substance abuse

- Health care employment in settings with tuberculosis patients

- Chest X-ray findings consistent with previous tuberculosis

We also searched for tuberculosis screening protocols prior to initiating treatment with anti-TNF-alpha drugs $(51,52)$, and we found that routine chest $\mathrm{X}$-ray was a common, widespread recommendation in various guidelines and studies. Regarding the use of TST, most guidelines and protocols favor its widespread use with the exception of the Swiss guidelines (52). German guidelines propose that a TST be done only if discrepancy exists between strong epidemiological evidence of prior tuberculosis exposure and negative IGRA (53). UK guidelines do not recommend TST for immunosuppressed patients (51) and the European guidelines establish that a TST be done on individuals without a history of $B C G$ vaccination (12). 
Regarding TST positivity, three study groups considered a result of $>5 \mathrm{~mm}$ to be positive $(31,33,53)$. The French guidelines considered a $>10 \mathrm{~mm}$ (33) result to be positive, while in the UK, the positivity corresponds to $5 \mathrm{~mm}$ in unvaccinated patients and $15 \mathrm{~mm}$ in vaccinated patients (52). In the USA, a result of more than $5 \mathrm{~mm}$ is considered positive if the patient is immunosuppressed, more than 10 $\mathrm{mm}$ is positive for patients in certain risk groups, and $15 \mathrm{~mm}$ if the patient is at low risk (46)

Due to the presence of false positives when screening with TST among individuals with prior exposure to BCG vaccine (54), more reliable diagnostic tools have been developed in recent years. One of the most widely used nowadays in some settings are the IGRA, which have better sensitivity than TST in immunocompromised subjects, as well as higher specificity. IGRA also have the advantage of not being influenced by prior vaccination with BCG or contact with nontuberculous mycobacteria $(8,52,54,55)$.

The IGRA quantify interferon-gamma production from $T$ cells and are based on the principle that $T$ cells already sensitized to tuberculosis antigens produce high IFN- $\gamma$ levels when they are exposed again. As a consequence, IGRA can improve latent tuberculosis infection detection specificity in BCGvaccinated populations (55). This testing method had been adopted as evidence in tuberculosis screening in only three of seven guidelines consulted (12, $19,52,53)$. Despite the evidence on the use of IGRA shown in some studies, some research has demonstrated that TST and IGRA responses vary substantially among different groups of immunocompromised patients, and are poor predictors of the development of tuberculosis in them (56).

Regarding the treatment for latent tuberculosis infection or active tuberculosis, each consensus suggests a specific type of regimen, differing in the drugs used and the duration of treatment. The different treatment protocols are summarized in table 3.

The clinical guidelines for the management of patients with rheumatoid arthritis in Colombia were issued in 2014 (57), and they do not include a screening protocol for active tuberculosis nor latent tuberculosis infection despite the high incidence of tuberculosis in the country. Nevertheless, the guidelines recommend ruling out latent or active tuberculosis in patients under treatment with conventional or biologic DMARD as a good clinical practice. It is of great importance to develop recommendations on this topic and to encourage further local studies to evaluate the most appropriate treatment in cases of latent tuberculosis infection and active tuberculosis when anti-TNF-alpha therapy is required. As shown in table 3 , there is no international consensus, and proposed therapies are tailored to the characteristics of each country.

It is necessary to adopt a strict and well-established public health policy in Colombia to enable a decrease in tuberculosis incidence among patients receiving biological therapy. This is the only possible way to reduce tuberculosis-associated morbidity and mortality.

The use of anti-TNF-alpha therapy has shown that disease progression in rheumatoid arthritis can be reduced satisfactorily, but it is essential to carry out suitable screening prior to its administration. Patients should also be monitored for any respiratory symptoms and, if found, clinicians should suspect the presence of pulmonary tuberculosis, especially in cases where clinical, laboratory, and image findings allow for a wide range of different diagnoses.

However, even if proper screening is done prior to the start of anti-TNF-alpha therapy, the risk of tuberculosis remains, including cases with prior normal chest X-ray and negative TST (58-60). In this sense, some groups have suggested the use of new screening tests after the start of antiTNF-alpha therapy $(28,45,60)$. Some institutions are adopting protocols that promote the periodic search for tuberculosis in patients under biological therapy, as proposed by Tae Sun, et al. (25), who did tuberculosis screening three, six and nine months after the start of anti-TNF-alpha therapy, and annually after that. Other authors recommend tuberculosis screening every year $(12,61,62)$.

To achieve a significant reduction in morbidity and mortality, which ultimately would improve the patient's quality of life, clinicians need to be very meticulous in the search for risk factors increasing the incidence of infectious diseases, and decide which screening test is most suitable for each individual patient $(5,8)$. Lastly, patients' safety and quality of life should be the main objectives of every rheumatologic treatment.

In conclusion, patients with autoimmune or autoinflammatory diseases that benefit from antiTNF-alpha therapy should be screened for infectious agents, especially tuberculosis. Different tests have been developed to detect latent tuberculosis 
Table 3. Recommendations for the treatment of tuberculosis in patients requiring anti-TNF-alpha therapy

\begin{tabular}{|c|c|c|c|c|}
\hline \multirow[t]{2}{*}{ Country } & \multicolumn{2}{|l|}{ Tuberculosis treatment } & \multicolumn{2}{|c|}{$\begin{array}{l}\text { Time of use of the anti-TB therapy before anti- } \\
\text { TNF-alpha therapy }\end{array}$} \\
\hline & $\begin{array}{l}\text { Latent tuberculosis } \\
\text { infection }\end{array}$ & Active tuberculosis & $\begin{array}{l}\text { Latent tuberculosis } \\
\text { infection }\end{array}$ & $\begin{array}{l}\text { Active } \\
\text { tuberculosis }\end{array}$ \\
\hline European (12) & $\begin{array}{l}\text { Isoniazid for } 9-12 \text { months } \\
\text { or rifampicin plus isoniazid } \\
\text { for three months }\end{array}$ & & $\begin{array}{l}\text { Four weeks after start of } \\
\text { anti-tuberculosis therapy }\end{array}$ & $\begin{array}{l}\text { After completion } \\
\text { of anti-tuberculosis } \\
\text { therapy }\end{array}$ \\
\hline USA (30) & Isoniazid for nine months & & $\begin{array}{l}\text { After completion of anti- } \\
\text { tuberculosis therapy }\end{array}$ & $\begin{array}{l}\text { After completion } \\
\text { of anti-tuberculosis } \\
\text { therapy }\end{array}$ \\
\hline Spain (31) & Isoniazid for nine months & & & \\
\hline France (32) & $\begin{array}{l}\text { Rifampicin plus isoniazid } \\
\text { for three months }\end{array}$ & $\begin{array}{l}\text { Rifampicin, isoniazid and } \\
\text { pyrazinamide (single dose); } \\
\text { afterwards the pyrazinamide } \\
\text { is stopped and the two } \\
\text { other drugs continued in } \\
\text { combination }\end{array}$ & $\begin{array}{l}\text { Three weeks after start of } \\
\text { anti-tuberculosis therapy }\end{array}$ & $\begin{array}{l}\text { Two months after } \\
\text { the end of anti- } \\
\text { tuberculosis therapy }\end{array}$ \\
\hline Portugal (33) & $\begin{array}{l}\text { Isoniazid, rifampicin } \\
\text { and pyrazinamide for } \\
\text { two months }\end{array}$ & & & \\
\hline Germany (45) & Isoniazid for nine months & & $\begin{array}{l}\text { After completion of anti- } \\
\text { tuberculosis therapy; } \\
\text { however, anti-TNF-alpha } \\
\text { therapy can be started two } \\
\text { months after start of anti- } \\
\text { tuberculosis therapy }\end{array}$ & \\
\hline $\begin{array}{l}\text { Switzerland } \\
(44)\end{array}$ & $\begin{array}{l}\text { Isoniazid for nine } \\
\text { months or rifampicin } \\
\text { for four months }\end{array}$ & & $\begin{array}{l}\text { One month after the start of } \\
\text { anti-tuberculosis therapy }\end{array}$ & \\
\hline UK (43) & $\begin{array}{l}\text { Isoniazid for six months or } \\
\text { rifampicin plus isoniazid } \\
\text { for three months }\end{array}$ & & $\begin{array}{l}\text { After completion of the anti- } \\
\text { tuberculosis therapy }\end{array}$ & $\begin{array}{l}\text { After two months } \\
\text { of the start of anti- } \\
\text { tuberculosis therapy }\end{array}$ \\
\hline
\end{tabular}

infection (PPD, IGRA and chest radiography), as its proper and timely detection is key to preventing morbidity and mortality in patients with anti-TNFalpha therapy, given that these drugs mechanism of action decreases the immune system ability to form the tuberculosis granuloma. This interference with the granulomatous immune response increases the risk and predisposes patients to pulmonary, extrapulmonary or disseminated tuberculosis in the context of immunosuppression, with its subsequent complications, such as in the case reported here. Likewise, it is essential to establish internal and national guidelines to clearly define all the parameters and periodicity of tuberculosis screening once the anti-TNF-alpha is introduced.

\section{Acknowledgments}

The authors would like to express their gratitude to the members of the Centro de Estudio de Enfermedades Autoinmunes (CREA) for their fruitful discussions and contributions.

\section{Conflicts of interest}

The authors declare that they have no potential conflicts of interest regarding this work.

\section{Financing}

No funding was received.

\section{References}

1. Anaya JM, Shoenfeld Y, Rojas-Villarraga A, Levy RA, Cervera R. Autoimmunity from bench to bedside. First edition. Bogotá: Universidad del Rosario; 2013. p. 381-2.

2. Smolen JS, Aletaha D, Bijlsma JWJ, Breedveld FC, Boumpas D, Burmester G, et al. Treating rheumatoid arthritis to target: Recommendations of an international task force. Ann Rheum Dis. 2010;69:631-7. https://doi. org/10.1136/ard.2009.123919

3. Gorter SL, Bijlsma JM, Cutolo M, Gómez-Reino J, Kouloumas M, Smolen JS, et al. Current evidence for the management of rheumatoid arthritis with glucocorticoids: A systematic literature review informing the EULAR recommendations for the management of rheumatoid arthritis. Ann Rheum Dis. 2014;69:1010-14. https://doi. org/10.1136/ard.2009.127332 
4. Monaco C, Nanchahal J, Taylor P, Feldmann M. Anti-TNF therapy: Past, present and future. Int Immunol. 2015;27:5562. https://doi.org/10.1093/intimm/dxu102

5. Cantini F, Nannini C, Niccoli L, lannone F, Delogu G, Garlaschi G, et al. Guidance for the management of patients with latent tuberculosis infection requiring biologic therapy in rheumatology and dermatology clinical practice. Autoimmun Rev. 2015;14:503-9. https://doi.org/10.1016/j. autrev.2015.01.011

6. Vivar $\mathbf{N}$, van Vollenhoven RF. Advances in the treatment of rheumatoid arthritis. F1000Prime Rep. 2014;6:31. https:// doi.org/10.12703/P6-31

7. Ali T, Kaitha S, Mahmood S, Ftesi A, Stone J, Bronze MS. Clinical use of anti-TNF therapy and increased risk of infections. Drug Healthc Patient Saf. 2013;5:79-99. https:// doi.org/10.2147/DHPS.S28801

8. Murdaca G, Spanò F, Contatore M, Guastalla A, Penza E, Magnani $\mathrm{O}$, et al. Infection risk associated with anti-TNF-a agents: A review. Expert Opin Drug Saf. 2015;14:571-82. https://doi.org/10.1517/14740338.2015.1009036

9. Joshi P, Dhaneshwar SS. An update on disease modifying antirheumatic drugs. Inflamm Allergy Drug Targets. 2014; 13:249-61. https://doi.org/10.2174/1871528113041409151 52102

10. Tracey D, Klareskog L, Sasso EH, Salfeld JG, Tak PP. Tumor necrosis factor antagonist mechanisms of action: A comprehensive review. Pharmacol Ther. 2008;117:244-79. https://doi.org/10.1016/j.pharmthera.2007.10.001

11. Koo S, Marty FM, Baden LR. Infectious complications associated with immunomodulating biologic agents. Hematol Oncol Clin North Am. 2011;25:117-38. https://doi. org/10.1016/j.hoc.2010.11.009

12. Solovic I, Sester M, Gómez-Reino JJ, Rieder HL, Ehlers $\mathrm{S}$, Milburn HJ, et al. The risk of tuberculosis related to tumour necrosis factor antagonist therapies: A TBNET consensus statement. Eur Respir J. 2010;36:1185-206. https://doi.org/10.1183/09031936.00028510

13. Maini RN, Feldmann M. How does infliximab work in rheumatoid arthritis? Arthritis Res. 2002;4:S22-8. https:// doi.org/10.1186/ar549

14. Goel N, Stephens S. Certolizumab pegol. MAbs. 2010;2: 137-47.

15. Wallis RS. Tumour necrosis factor antagonists: Structure, function, and tuberculosis risks. Lancet Infect Dis. 2008;8: 601-11. https://doi.org/10.1016/S1473-3099(08)70227-5

16. Cheifetz A, Smedley M, Martin S, Reiter M, Leone G, Mayer $L$, et al. The incidence and management of infusion reactions to infliximab: A large center experience. Am J Gastroenterol. 2003;98:1315-24. https://doi.org/10.1111/j. 1572-0241.2003.07457.x

17. Rosenblum H, Amital H. Anti-TNF therapy: Safety aspects of taking the risk. Autoimmun Rev. 2011;10:563-8. https:// doi.org/10.1016/j.autrev.2011.04.010

18. Cacciapaglia F, Navarini L, Menna P, Salvatorelli E, Minotti G, Afeltra A. Cardiovascular safety of anti-TNFalpha therapies: Facts and unsettled issues. Autoimmun Rev. 2011;10:631-5. https://doi.org/10.1016/j.autrev.2011.04.014
19. Xie X, Li F, Chen J-W, Wang J. Risk of tuberculosis infection in anti-TNF-a biological therapy: From bench to bedside. J Microbiol Immunol Infect. 2014;47:268-74. https://doi. org/10.1016/j.jmii.2013.03.005

20. Yasui K. Immunity against Mycobacterium tuberculosis and the risk of biologic anti-TNF-a reagents. Pediatr Rheumatol Online J. 2014;12:45. https://doi.org/10.1186/1546-0096$12-45$

21. Winthrop KL. Risk and prevention of tuberculosis and other serious opportunistic infections associated with the inhibition of tumor necrosis factor. Nat Clin Pract Rheumatol. 2006;2:602-10. https://doi.org/10.1038/ncprheum0336

22. Wallis RS, Broder M, Wong J, Beenhouwer D. Granulomatous infections due to tumor necrosis factor blockade: Correction. Clin Infect Dis. 2004;39:1254-5. https://doi. org/10.1086/424455

23. World Health Organization. Tuberculosis. First edition. Accessed: 12 de octubre de 2015. Available from: http:// www.who.int/mediacentre/factsheets/fs104/en/

24. World Health Organization. Tuberculosis, Colombia 2012. First edition. Accessed: 25 de noviembre de 2015. Available from: https://extranet.who.int/sree/Reports?op=Replet\&name= \%2FWHO_HQ_Reports\%2FG2\%2FPROD\%2FEXT\%2FTBCou ntryProfile\& $I S O 2=C O \& L A N=E N \&$ outtype $=h t m l$

25. Shim TS. Diagnosis and treatment of latent tuberculosis infection due to initiation of anti-TNF therapy. Tuberc Respir Dis (Seoul). 2014;76:261-8. https://doi.org/10.4046/ trd.2014.76.6.261

26. Dixon WG, Hyrich KL, Watson KD, Lunt M, Galloway J, Ustianowski A, et al. Drug-specific risk of tuberculosis in patients with rheumatoid arthritis treated with anti-TNF therapy: Results from the British Society for Rheumatology Biologics Register (BSRBR). Ann Rheum Dis. 2010;69:5228. https://doi.org/10.1136/ard.2009.118935

27. Tubach $\mathbf{F}$, Salmon D, Ravaud $\mathbf{P}$, Allanore $\mathbf{Y}$, Goupille $\mathbf{P}$, Bréban $\mathbf{M}$, et al. Risk of tuberculosis is higher with antitumor necrosis factor monoclonal antibody therapy than with soluble tumor necrosis factor receptor therapy: The three-year prospective French Research Axed on Tolerance of Biotherapies registry. Arthritis Rheum. 2009;60:1884-94. https://doi.org/10.1002/art.24632

28. Lee H, Park HY, Jeon K, Jeong B-H, Hwang J-W, Lee J, et al. QuantiFERON-TB Gold In-Tube assay for screening arthritis patients for latent tuberculosis infection before starting anti-tumor necrosis factor treatment. PLoS One. 2015; 10:e0119260. https://doi.org/10.1371/journal.pone.0119260

29. Rojas-Villarraga A, Agudelo CA, Pineda-Tamayo R, Porras A, Matute G, Anaya JM. Tuberculosis in patients treated with tumor necrosis factor-alpha antagonists living in an endemic area. Is the risk worthwhile? Biomédica. 2007; 27:159-71. https://doi.org/10.7705/biomedica.v27i2.212

30. Centers for Disease Control and Prevention.Tuberculosis associated with blocking agents against tumor necrosis factor-alpha--California, 2002-2003. MMWR Morb Mortal Wkly Rep. 2004;53:683-6.

31. Carmona L, Gómez-Reino JJ, Rodríguez-Valverde V, Montero D, Pascual-Gómez E, Mola EM, et al. Effectiveness of recommendations to prevent reactivation of latent tuberculosis infection in patients treated with tumor necrosis factor antagonists. Arthritis Rheum. 2005;52:1766-72. https://doi.org/10.1002/art.21043 
32. Mariette X, Salmon D. French guidelines for diagnosis and treating latent and active tuberculosis in patients with RA treated with TNF blockers. Ann Rheum Dis. 2003;62:791. https://doi.org/10.1136/ard.62.8.791

33. Fonseca JE, Canhão $\mathbf{H}$, Silva C, Miguel C, Mediavilla MJ, Teixeira A, et al. Tuberculosis in rheumatic patients treated with tumour necrosis factor alpha antagonists: The Portuguese experience. Acta Reumatol Port. 2006;31: 247-53.

34. Caballero CV, Pinzón L. Artritis reumatoide tratada con inhibidores del factor de necrosis tumoral a (Anti-TNF-a) y tuberculosis pulmonar. Salud Uninorte. 2006;22:29-39.

35. Hidalgo P, Echeverri J, Gutiérrez JM. Tuberculosis pleural asociada con adalimumab, en un paciente con artritis reumatoide. Infectio. 2010;14:47-54. https://doi.org/10. 1016/S0123-9392(10)70092-8

36. Londoño P, Fernández D, Salazar J, Saiibi D, Molina J, Valle R, et al. Cambio en la capacidad funcional, calidad de vida y actividad de la enfermedad, en un grupo de pacientes colombianos con artritis reumatoide refractaria (sic) al tratamiento convencional, que recibieron terapia con infliximab como medicamento de rescate. Rev Fac Med. 2009;17:40-9.

37. Machado J, Moncada JC, Pineda R. Perfil de utilización de los anti-factor de necrosis tumoral en pacientes de Colombia. Biomédica. 2011;31:250-7. https://doi.org/10. 7705/biomedica.v31i2.319

38. Martínez JB, Medina Y, Parga R, Restrepo JF, Iglesias A, Rondón F. Reactivación de tuberculosis pulmonar (TBC) con el uso de antagonistas del factor de necrosis tumoral alfa (FNTa) en artritis reumatoide. A propósito de un caso. Rev Colomb Reumatol. 2005;12:54-61.

39. Muñoz OM, Hurtado M, Fernández D, Hidalgo $P$, Gutiérrez JM. Conversión de tuberculosis latente en un grupo de pacientes tratados con terapia biológica en una unidad de Reumatología. Rev Colomb Neumol. 2014;26:116-22.

40. Insuasty JS, Bolívar A, Calvo LS, Roberto SL. Tuberculosis peritoneal simulando cáncer de ovario. Acta Med Colomb. 2014;39:383-7.

41. Vega J, Pinto LF, Muñoz C, Márquez JD, Rodríguez LM, Velázquez CJ. Infecciones en pacientes con artritis reumatoide: medicamentos moduladores de la respuesta biológica versus fármacos modificadores de la enfermedad. Seguimiento a un año. Rev Colomb Reumatol. 2013;21:27-34.

42. Wang MH, Liu X, Shen B. Disseminated tuberculosis in a patient taking anti-TNF therapy for Crohn's disease. ACG Case Reports J. 2015;3:45-8. https://doi.org/10.14309/crj. 2015.97

43. Tanaka T, Sekine A, Tsunoda Y, Takoi H, Lin S-Y, Yatagai $\mathbf{Y}$, et al. Central nervous system manifestations of tuberculosis-associated immune reconstitution inflammatory syndrome during adalimumab therapy: A case report and review of the literature. Intern Med. 2015;54:847-51. https://doi.org/10.2169/internalmedicine.54.2828

44. van der Have $M$, Belderbos TD, Fidder HH, Leenders $M$, Dijkstra G, Peters CP, et al. Screening prior to biological therapy in Crohn's disease: Adherence to guidelines and prevalence of infections. Results from a multicentre retrospective study. Dig Liver Dis. 2014;46:881-6. https:// doi.org/10.1016/j.dld.2014.07.006
45. Raval A. Brief communication: Characteristics of spontaneous cases of tuberculosis associated with infliximab. Ann Intern Med. 2007;147:699-702. https://doi.org/10.7326/00034819-147-10-200711200-00006

46. Keane J, Gershon S, Wise RP, Mirabile-Levens E, Kasznica J, Schwieterman WD, et al. Tuberculosis associated with infliximab, a tumor necrosis factor alphaneutralizing agent. N Engl J Med. 2001;345:1098-104. https://doi.org/10.1056/NEJMoa011110.

47. Elbek O, Uyar M, Aydin N, Börekçi S, Bayram N, Bayram $\mathbf{H}$, et al. Increased risk of tuberculosis in patients treated with antitumor necrosis factor alpha. Clin Rheumatol. 2009;28:421-6. https://doi.org/10.1007/s10067-008-1067-x

48. Jick SS, Lieberman ES, Rahman MU, Choi HK. Glucocorticoid use, other associated factors, and the risk of tuberculosis. Arthritis Rheum. 2006;55:19-26. https://doi. org/10.1002/art.21705

49. Lorenzetti R, Zullo A, Ridola L, Diamanti AP, Laganà B, Gatta L, et al. Higher risk of tuberculosis reactivation when anti-TNF is combined with immunosuppressive agents: A systematic review of randomized controlled trials. Ann Med. 2014;46:547-54. https://doi.org/10.3109/07853890. 2014.941919

50. Brode SK, Jamieson FB, Ng R, Campitelli MA, Kwong JC, Paterson JM, et al. Increased risk of mycobacterial infections associated with anti-rheumatic medications. Thorax. 2015;70:677-82. https://doi.org/10.1136/thoraxjnl2014-206470

51. Ledingham J, Wilkinson C, Deighton C. British Thoracic Society (BTS) recommendations for assessing risk and managing tuberculosis in patients due to start anti-TNFalpha treatments. Rheumatology (Oxford). 2005;44:1205-6. https://doi.org/10.1093/rheumatology/kei103

52. Beglinger C, Dudler J, Mottet C, Nicod L, Seibold F, Villiger PM, et al. Screening for tuberculosis infection before the initiation of an anti-TNF-alpha therapy. Swiss Med Wkly. 2007;137:620-2.

53. Diel R, Hauer B, Loddenkemper R, Manger B, Krüger K. Recommendations for tuberculosis screening before initiation of TNF-alpha-inhibitor treatment in rheumatic disease. Pneumologie. 2009;63:329-34. https://doi.org/10. 1055/s-0029-1214673

54. Hur Y-G, Kang YA, Jang S-H, Hong JY, Kim A, Lee SA, et al. Adjunctive biomarkers for improving diagnosis of tuberculosis and monitoring therapeutic effects. J Infect. 2015;70:346-55. https://doi.org/10.1016/j.jinf.2014.10.019

55. Brock I, Ruhwald M, Lundgren B, Westh H, Mathiesen LR, Ravn P. Latent tuberculosis in HIV positive, diagnosed by the $M$. tuberculosis specific interferon-gamma test. Respir Res. 2006;7:56. https://doi.org/10.1186/1465-9921-7-56

56. Sester M, van Leth F, Bruchfeld J, Bumbacea D, Cirillo DM, Dilektasli AG, et al. Risk assessment of tuberculosis in immunocompromised patients. A TBNET Study. Am J Respir Crit Care Med. 2014;190:1168-76. https://doi.org/10. 1164/rccm.201405-09670C

57. Quintana-López G, Grillo-Ardila C, Méndez P, Vallejo M, Guevara $\mathbf{O}$, Velásquez $\mathbf{C}$, et al. Guía de práctica clínica para la detección temprana, diagnóstico y tratamiento de la artritis reumatoide. Primera edición. Bogotá, D.C.: Ministerio de Salud y Protección Social; 2014. 
58. Debeuckelaere C, De Munter P, van Bleyenbergh P, De Wever W, van Assche G, Rutgeerts $P$, et al. Tuberculosis infection following anti-TNF therapy in inflammatory bowel disease, despite negative screening. J Crohns Colitis. 2014;8:550-7. https://doi.org/10.1016/j.crohns.2013.11.008

59. Çekiç C, Aslan F, Vatansever S, Topal F, Yüksel ES, Alper E, et al. Latent tuberculosis screening tests and active tuberculosis infection rates in Turkish inflammatory bowel disease patients under anti-tumor necrosis factor therapy. Ann Gastroenterol. 2015;28:241-6.

60. Bernal JA, Andrés M, Jovaní V, García-Sevila R, Begazo A, Vela P. Primary tuberculosis infection in patients treated with tumor necrosis factor-alpha antagonists and a negative initial screening. Reumatol Clin. 2016;12:81-4. https://doi. org/10.1016/j.reuma.2015.04.001

61. Smith MY, Attig B, McNamee L, Eagle T. Tuberculosis screening in prescribers of anti-tumor necrosis factor therapy in the European Union. Int J Tuberc Lung Dis. 2012;16:1168-73. https://doi.org/10.5588/ijtld.12.0029

62. Ferreira BA, Ribeiro S, Meireles J, Correia A, Duarte R. Tuberculosis screening and compliance rate with guidelines among northern Portuguese hospitals prescribers of antiTNF therapy. Rev Port Pneumol. 2014;21:99-101. https:// doi.org/10.1016/j.rppnen.2014.09.008 